\title{
IAMJ
}

INTERNATIONAL

AYURVEDIC

MEDICAL JOURNAL

Research Article

ISSN: 2320-5091

Impact Factor: 6.719

\section{CLINICAL STUDY OF KANTKARI AVLEHA AND VASA AVLEHA IN THE MANAGEMENT OF TAMAK SHWASA W.S.R TO BRONCHIAL ASTHMA}

\author{
Nishu Raina
}

Assistant Professor, Kayachikitsa, Dayanand Ayurvedic College and Hospital Jalandhar, Punjab, India

Corresponding Author: nishu.raina2010@gmail.com

https://doi.org/10.46607/iamj08p5022020

(Published online: January 2021)

Open Access

(C) International Ayurvedic Medical Journal, India 2021

Article Received: 02/02/2020 - Peer Reviewed: 05/02/2021 - Accepted for Publication: 09/02/2021

Check for updates

\begin{abstract}
Asthma is a chronic inflammatory disease which causes the lining of the airways to become swollen and inflamed, which further leads to production of thick, sticky mucous. These changes further cause the airways to become narrow, making it difficult for the patient to breathe properly. In this study, efficacy of formulations like Vasavaleha and Kantakari Avaleha are studied in the patients of Tamaka Shwasa w.s.r to bronchial asthma. Tamaka Shwasa is a Yapya Vyadhi. The etiopathogenesis, signs, and symptoms of Tamaka Shwasa may be correlated with Bronchial Asthma. Each patient reacts differently to the factors that trigger asthma and are treated symptomatically. Asthma is the most common chronic allergic disorder in childhood and third leading cause of hospitalization under the age of 15 years. As it is a Kapha-Vata predominant disorder, Ayurvedic medicine may help to decrease the recurrence, improve immunity, and check symptoms naturally. With this aim, a clinical study was undertaken on two groups for a duration of 6 weeks. The Kantakari Avaleha and Vasa Avaleha were given orally, separately in both the groups. All the patients were kept under strict dietary control during the treatment. The observation on the effect of therapy was encouraging and showed less recurrence.
\end{abstract}

Keywords: Kantakari Avaleha, childhood asthma, Tamaka Shwasa, Vasa Avaleha 


\section{INTRODUCTION}

Asthmatic patients' most important complaint is difficulty in breathing. In Ayurveda under, 'Swasa Roga' obstructed passage of air is seen to be caused by the abnormal movement of Vata either on its own (where dry and astringent qualities cause the constriction and contraction of the smooth muscles) or in conjunction with an obstruction caused by excess Kapha Dosha, whose nature is to obstruct the tract. Basically, it is the presence of Vata, which dries out the accumulated mucus causing it to become thick and sticky. Symptoms of Bronchial Asthma are compared with those of "Tamaka Shwasa ", which is basically disorder of Pranavaha Srotas. Shwasa word indicates both physiological and pathological state of respiration. Tamaka Shwasa is one of the five types of disease Shwasa. Tamaka Shwasa is a disease mainly of Pranavaha Srotas ${ }^{1}$. The signs, symptoms, and etiopathogenesis of Bronchial Asthma explained in modern diagnosis have a lot of similarities with the disease entity Tamaka Shwasa. Both Ayurveda and modern medical Science agree regarding the Nidana of the disease as host factors (Ninja Hetus - Doshadushti and Ama) and Environmental factors (Agantuja Hetus - Raja, Dhuma, Pragvata, etc). It can be easily correlated with the allergic condition. Nidana Parivarjanam hence plays a key role in the management strategy in both sciences ${ }^{2}$.

The prevalence of Bronchial Asthma has increased continuously since the 1970s, and now affects an estimated 4 to $7 \%$ of the people worldwide. it has multi factor causation. For many people with asthma, symptoms only occur when an acute 'attack' is triggered by an allergen such as pollen or dust mite. Asthma is the most common chronic disease of childhood, and yet many parents know little about it. In children aged 5 to 14 years, the rate of death from asthma almost doubled between 1980 and 1993 .
Among children aged 0 to 4 years in 1993, blacks were six times more likely to die from asthma than whites3.

\section{Aims and objectives}

Clinical study of the efficacy of Yogas i.e., Kantakari Avaleha (KA) and Vasa Avaleha (VA) in the management of Tamaka Shwasa with special reference to Bronchial Asthma.

Materials and Methods- Patients attending the OPD of Kayachikitsa Dac Jalandhar, having the complaint of Tamaka Shwasa like Paroxysm of breathlessness, Cough, Awaking in night etc

\section{Selection of patients: -}

Inclusion criteria: Age group between 14 and 50 years. Classical symptoms of Tamaka Shwasa with emphasis on symptoms like wheezing, shortness of breath, tightness in chest, and cough.

\section{Exclusion Criteria:}

- Severe cases of Asthma with complications like suspected infection, large airway lesions, heart diseases, etc.

- Cardiac complaints, other chronic debilitating diseases like Tuberculosis, Acquired Immune Deficiency Syndrome etc, other systemic and endocrine complaints associated with any degree of Asthma.

Diagnosis Criteria: It had been based on the specially prepared proforma, including all clinical signs and symptoms of the disease, in which detailed history had been taken.

Preparation of the Drugs: Kantakari Avaleha as described in Sharanghara Madhyama Khand (8/5-9) $\{4\}$ was selected. The list of the herbs is as mentioned in Table 1. In another group, Vasaavaleha ${ }^{5}$, as mentioned in Bhaishajya Ratnavali in Kasa Roga Chikitsa (16/179-181) was selected. The ingredients are enlisted in Table 2 in equal quantity for preparation of Avaleha. 
Table 1: Contents of Kantakari Avaleha

\begin{tabular}{|l|l|l|}
\hline Drug & Latin name & Quantity \\
\hline Kantkari & Solanum Xanthocarpum & $4.8 \mathrm{~kg}$ Kantkari added in 12.28 litre water and reduced to 3.072 l \\
\hline Guduchi & Tinospora Cordifolia & $48 \mathrm{~g}$ \\
\hline Chavya & Piper Cubeba & $-d o-$ \\
\hline Chitraka & Plumbago Zeylanica & $-d o-$ \\
\hline Musta & Cyperus Rotundus & $-d o-$ \\
\hline Karkatshringi & Pistacia Integerrima & $-d o-$ \\
\hline Trikatu Churna & Pepper, Longer Pepper And Ginger & - do- \\
\hline Dhanvayasa & Alhagi Pseudalghi & $-d o-$ \\
\hline Bharangi & Clerodendron Serratum & $-d o-$ \\
\hline Rasna & Pluchea Lanceolata & $-d o-$ \\
\hline Shati & Hedychium Spicatum & $-d o-$ \\
\hline Sugar & - & $96.8 \mathrm{~g}$ \\
\hline Ghee & & $384 \mathrm{~g}$ \\
\hline Sesame Oil & - & $-d o-$ \\
\hline Vamshalochana & - & $48 \mathrm{~g}$ \\
\hline Long Pepper & - & $-d o-$ \\
\hline
\end{tabular}

Table 2: Contents of Vasa Avaleha

\begin{tabular}{|l|l|l|}
\hline Composition & Botanical name & Dose \\
\hline Vasa & Adhatoda Vasica & $1(64$ tola $)$ \\
\hline Sharkara & Sugar Candy & $1 / 2(32$ tola $)$ \\
\hline Go ghrita & Clarified Butter & $1 / 8(8$ tola $)$ \\
\hline Pippali & Piper Longum & - do- \\
\hline Madhu & Honey & $1 / 2(32$ tola $)$ \\
\hline
\end{tabular}

Though both the drugs are of known efficacy, the patient's age group due to their bad palatability did not accept the forms of the medicines, Kwatha, etc. Taking the aspect of palatability and acceptability into effective consideration, the medicines were planned to be administered in Avaleha form. To make the Avaleha form of above-mentioned Kashaya Siddhantas told by Sharangdhara had been followed.

Posology: The dose is shown in Table 3.

Table 3: Dose and duration of trial drugs

\begin{tabular}{|l|l|l|l|l|}
\hline Group & Dose & Anupana & Duration & Follow up \\
\hline Group A & $6 \mathrm{GM}$ & Lukewarm water & 6 Weeks & 1 month \\
\hline Group B & $6 \mathrm{GM}$ & Lukewarm water & 6 weeks & 1 month \\
\hline
\end{tabular}

\section{Criteria of Assessment}

1. Clinical features of Tamaka Shwasa w.s.r Bronchial Asthma

2. Improvement in frequency, intensity, and duration of symptoms had been considered.

3. Hematological investigations.

4. Absolute eosinophil count.

Effect of Therapy: - The clinical efficacy of the drug was analyzed statistically on all the symptoms

mentioned in the assessment criteria. Initially, the variation and significance of effect seen within the 18 patients were calculated by paired t test. The difference of individual score SD was calculated with Standard Error in Mean (SEM). These data are shown as Mean \pm SEM. Then, to more specifically quantify the percentage of improvement in each patient, this was also calculated using the formula $(\mathrm{BT}-\mathrm{AT}) \times 100 / \mathrm{BT}^{6}$. 
Table 4: Effect of therapy is evaluated as:-

\begin{tabular}{|l|l|}
\hline Improvement & Percentage \\
\hline No improvement & $0-25 \%$ \\
\hline Mild improvement & $>25-50 \%$ \\
\hline Moderate improvement & $>50-75 \%$ \\
\hline Markedly improvement & $>75-<100 \%$ \\
\hline Complete remission & $100 \%$ \\
\hline
\end{tabular}

\section{Observations and Results: -}

Table 5: General observations

\begin{tabular}{|l|l|}
\hline Observations & Results(max.\%) \\
\hline Age & $57.69 \%$ \\
\hline Gender (male) & 73.03 \\
\hline High school (paternal education) & 46.1 \\
\hline -do-(maternal education) & 26.9 \\
\hline Chronicity (0-3 Years) & 65.5 \\
\hline Frequency (weekly) & 34.6 \\
\hline Intensity (night and midnight) & 53.8 \\
\hline Morning & 50 \\
\hline Family history (+ve) & 19.2 \\
\hline Nidana (Sheeta \& Ruksha Ahara) & 80.8 \\
\hline Shleshmala Ahara & 57.7 \\
\hline Visham Asana (dietary habits) & 42.3 \\
\hline Madhura Rasa (dominant Rasa in Ahara) & 61.5 \\
\hline Vata-Pitta Prakriti (Prakriti) & 42.31 \\
\hline Kapha-Vata Prakriti (Prakriti) & 38.6 \\
\hline Agni (Mandagni) & 65.38 \\
\hline
\end{tabular}

Table 6: Effect of therapy on cardinal features in Tamaka Shwasa (b. asthma) in group - A

\begin{tabular}{|l|l|l|l|l|l|l|l|l|}
\hline Symptoms & $\mathrm{n}$ & mean BT & mean AT & $\%$ & SD & SE & t & P \\
\hline Shwasakastata & 11 & 3.1 & 0.36 & 88.24 & 0.77 & 0.24 & 11.5 & $<0.001$ \\
\hline Shwasa Vega & -do- & 2.9 & 0.37 & 87.5 & 1.29 & 0.39 & 6.53 & $<0.001$ \\
\hline Vega Tivrata & -do- & 1.8 & .27 & 85 & 0.82 & 0.25 & 6.25 & $<0.001$ \\
\hline Vega Avadhi & -do- & 2.6 & .18 & 92.8 & 0.81 & 0.24 & 9.67 & $<0.001$ \\
\hline Asinolabhate Saukhyam & 07 & 1.8 & .000 & 100 & 0.69 & 0.26 & 7.12 & $<0.001$ \\
\hline Kasa & 11 & 3.09 & 0.9 & 70.5 & 0.87 & 0.26 & 8.28 & $<0.05$ \\
\hline Kaphanishthivan & 03 & 1.6 & 0.00 & 100 & 0.57 & 0.33 & 5 & $<0.001$ \\
\hline Wheezing & 08 & 2.38 & 0.25 & 89.47 & 0.83 & 0.3 & 7.2 & $<0.001$ \\
\hline Pihasa & 11 & 2.78 & 0.78 & 73.3 & 0.63 & 0.19 & 10.4 & $<0.001$ \\
\hline Urashool & 06 & 1.67 & 00 & 100 & 0.4 & 0.17 & 7 & $<0.001$ \\
\hline Shirograha & 05 & 1.6 & 00 & 100 & 0.89 & 0.4 & 4 & $<0.05$ \\
\hline Kanthodhvansana & 04 & 1.7 & 00 & 100 & 0.96 & 0.48 & 3.6 & $<0.05$ \\
\hline Nidra Labho & 11 & 1.8 & 0.18 & 90 & 0.5 & 0.15 & 10.7 & $<0.001$ \\
\hline Abhi Avarana Shakti & 10 & 2.5 & 0.6 & 76 & 0.73 & 0.23 & 8.1 & $<0.001$ \\
\hline Jarana Shakti & 09 & 1.6 & 0.22 & 86.67 & 0.73 & 0.24 & 5.9 & $<0.001$ \\
\hline Aruchi & 08 & 1.13 & 00 & 100 & 0.7 & 0.5 & 3 & $<0.001$ \\
\hline
\end{tabular}

Table 7: Effect of therapy on hematological parameters in 18 patients of Tamaka Shwasa (b. asthma) in group- A

\begin{tabular}{|l|l|l|l|l|l|l|l|l|}
\hline $\begin{array}{l}\text { Haematological } \\
\text { Parameters }\end{array}$ & $\mathrm{n}$ & mean BT & mean AT & $\%$ & SD & SE & t & P \\
\hline Haemoglobin $(\mathrm{Gm} \%)$ & 11 & 10.87 & 10.70 & 1.5 & 0.5 & 0.15 & 10.76 & $<0.1$ \\
\hline Tlc $/(\mathrm{Cmm})$ & 11 & 5975.84 & 7166.24 & -19.92 & 2721.36 & 820.52 & -1.45 & $<0.1$ \\
\hline
\end{tabular}




\begin{tabular}{|l|l|l|l|l|l|l|l|l|}
\hline Neutrophil & 11 & 49.56 & 56.9 & -14.86 & 11.10 & 3.34 & -2.19 & $<0.1$ \\
\hline Lymphocyte & 11 & 43.54 & 34.9 & 19.83 & 12.26 & 3.6 & 2.34 & $<0.01$ \\
\hline Eosinophil & 11 & 4.64 & 5.27 & -13.72 & 3.85 & 1.1 & -0.55 & $<0.1$ \\
\hline Monocytes & 11 & 2.72 & 2.9 & -6.67 & 0.75 & 0.2 & -0.8 & $<0.1$ \\
\hline ESR & 11 & 17.81 & 9.27 & 47.95 & 10.62 & 3.2 & 2.67 & $<0.1$ \\
\hline AEC & 11 & 422.72 & 531.8 & -25 & 504.39 & 152 & -0.71 & $<0.1$ \\
\hline Peak expiratory flow rate & 2 & 214 & 185 & 15 & 15.55 & 11 & 2.63 & $<0.1$ \\
\hline
\end{tabular}

Table 8: Effect of therapy on cardinal features in Tamaka Shwasa w.s.r. to bronchial asthma in 18 patients of group B

\begin{tabular}{|l|l|l|l|l|l|l|l|l|}
\hline Symptoms & $\mathrm{n}$ & Mean BT & Mean AT & $\%$ & SD & SE & t & P \\
\hline Shwasakastata & 7 & 2.71 & 0.14 & 88.24 & 0.77 & 0.24 & 11.5 & $<0.001$ \\
\hline Shwasa Vega & 7 & 2.29 & 0.29 & 87.5 & 1.29 & 0.39 & 6.53 & $<0.001$ \\
\hline Vega Tivrata & 7 & 2.0 & 00 & 85 & 0.82 & 0.25 & 6.25 & $<0.001$ \\
\hline Vega Avadhi & 7 & 2.14 & .14 & 92.8 & 0.81 & 0.24 & 9.67 & $<0.001$ \\
\hline Asinolabhate Saukhyam & 06 & 1.8 & .17 & 100 & 0.69 & 0.26 & 7.12 & $<0.001$ \\
\hline Kasa & 7 & 2.14 & 0.43 & 70.5 & 0.87 & 0.26 & 8.28 & $<0.05$ \\
\hline Kaphanishthivan & 05 & 1.6 & 0.00 & 100 & 0.57 & 0.33 & 5 & $<0.001$ \\
\hline Wheezing & 07 & 2.38 & 0.00 & 89.47 & 0.83 & 0.3 & 7.2 & $<0.001$ \\
\hline Pihasa & 07 & 2.29 & 0.78 & 73.3 & 0.63 & 0.19 & 10.4 & $<0.001$ \\
\hline Urashool & 06 & 2.26 & 00 & 100 & 0.4 & 0.17 & 7 & $<0.001$ \\
\hline Shirograha & 03 & 1.1 & 00 & 100 & 0.89 & 0.4 & 4 & $<0.05$ \\
\hline Kanthodhvansana & 05 & 1.2 & 00 & 100 & 0.96 & 0.48 & 3.6 & $<0.05$ \\
\hline Nidra Labho & 07 & 1.7 & 0.18 & 90 & 0.5 & 0.15 & 10.7 & $<0.001$ \\
\hline Abhi Avarana Shakti & 07 & 2.1 & 0.6 & 76 & 0.73 & 0.23 & 8.1 & $<0.001$ \\
\hline Jarana Shakti & 06 & 1.5 & 0.22 & 86.67 & 0.73 & 0.24 & 5.9 & $<0.001$ \\
\hline Aruchi & 05 & 1.6 & 00 & 100 & 0.7 & 0.5 & 3 & $<0.001$ \\
\hline
\end{tabular}

Table 9: Effect of therapy on Haematological parameters in 18 patients of Tamaka Shwasa (b. asthma) in group B

\begin{tabular}{|l|l|l|l|l|l|l|l|l|}
\hline $\begin{array}{l}\text { Haematological } \\
\text { parameters }\end{array}$ & $\mathrm{n}$ & mean BT & mean AT & $\%$ & SD & SE & t & P \\
\hline Haemoglobin (Gm\%) & 7 & 11.2 & 11.1 & 1.39 & 0.5 & 0.19 & 0.79 & $<0.1$ \\
\hline Tlc (/Cmm) & 7 & 8230.19 & 6973.4 & 15.27 & 2631.97 & 994.7 & 1.26 & $<0.1$ \\
\hline Neutrophil & 7 & 50.9 & 48.28 & 5.05 & 7.9 & 3.02 & 0.85 & $<0.1$ \\
\hline Lymphocyte & 7 & 40.3 & 43.57 & -8.15 & 6.6 & 2.52 & -1.30 & $<0.1$ \\
\hline Eosinophil & 7 & 6.2 & 5.43 & 13.6 & 4.3 & 1.62 & 0.52 & $<0.1$ \\
\hline Monocytes & 7 & 2.5 & 2.86 & -11.11 & 0.7 & 0.2 & -1 & $<0.1$ \\
\hline ESR & 7 & 12.57 & 17.43 & -38.63 & 19.8 & 7.5 & -0.65 & $<0.1$ \\
\hline AEC & 7 & 628.57 & 457.14 & 27.2 & 499 & 188.6 & 0.9 & $<0.1$ \\
\hline Peak expiratory flow rate & 3 & 200.67 & 177.67 & 5.54 & 18.7 & 7.09 & 1.3 & $<0.1$ *insignificant $<0.1$ \\
& & & & & & & & \\
\hline
\end{tabular}

Effect on Roga Bala, As the sample was small in both the groups, percentage-wise data are more reliable than the statistical data. In both the groups, symptoms related to Shwasakashtata were reduced but were statistically more highly significant in VA than KA, although trial drug decreases the Vega Tivrata and Vega Avadhi, between the treatment not whenever attacks come and not in emergency conditions. So, the trial drug plays an effective role. But, during the treatment, two patients reported an increase in the complaints with emergency modern medicine in control group VA. In Kasa and its associated symptoms, VA showed slightly better results than KA. Actually, Kasa, Kaphanisthvan, Urahashool, Shirograha, and symptoms are interrelated and cannot be assessed separately, but these all four symptoms make a complex feature which shows the different picture of Tamaka Shwasa, and symptoms of 
Shwasakashtata is also related with this. In Kapha nishthivan, both the groups showed significant results. In Parshva Shula and Shirograha, KA showed better results, but wheezing was decreased in VA, which may be due to decreased Kaphanisthvan and the mucous inside. In Peak expiratory flow rate KA showed better results. Effect on Agni Bala:- As far as Abhyavaharana Shakti is considered, In the group of KA, Abhyavarana Shakti was improved by $76 \%$, which was statistically highly significant. Similarly, as far as Jarnashakti is considered, In the group KA, Jarana Shakti was improved by $86.67 \%$, which was statistically highly significant. By the treatment of KA, all the parameters of Agni Bala showed improvement except Ruchi, which may be due to the ingredients of KA containing Pippali, Shunthi, Maricha, Dhanyaka, and Guduchi, which have more specific action on Agni. Effect on Chetasa Bala:- As far as Chetasa bala is considered, it is very much related to the counselling of the patients during the treatment. Nidra Labho-yathakalam may be due to release an attack of asthma in both the groups. Effect on other haematocrit values:- As far as Hematocrit values are considered, it is observed that in the KA Group, there was statistically no such significant changes observed in hematocrit values. what we note, was only that lymphocyte count got reduced by $19.23 \%$, Hbgm \% was improved by $1.51 \%$, eosinophil count was reduced by $24.19 \%$, and Erythrocyte sedimentation rate was reduced by 47.95\%. Effect on absolute eosinophil count: - In both the groups, there were no statistically significant changes in hematocrit values in comparison with VA $(27.27 \%)$. When comparison was done between two groups, it was observed that KA showed better results to decrease absolute eosinophil count (AEC) (39.69\%) as compared to the other one. Overall effect of therapy:When overall effect of therapy is observed, it is seen that In KA group, the highest number of patients (63.6\%) got markedly improvement, $18.18 \%$ was observed with moderate improvement, and $18.18 \%$ of patients were observed with complete remission. In the VA group, the highest number of patients (71.4\%) was markedly improved and $28.5 \%$ were observed with complete remission.

\section{DISCUSSION}

Since the Tamaka Shwasa is a Vata-Kapha-dominated disease, its incidence should be witnessed more either during the Balyavastha, which is the normal time of Kapha dominance, or the Vridhavastha, which is the normal time of Vata dominance ${ }^{6}$. This increased risk remained in males aged between 14 to 30 years, who were 1.3 times more likely to die from asthma than girls in that age group. After 30 years, the risk seems to even out between girls and boys ${ }^{7}$. In the present study, the maximum number of patients $(57.69 \%)$ were in the age group of 14 to 30 years, followed by $42.31 \%$ in $>30$ to 50 years age group. Although in all the classical literature, generally we do not find a mention of the relation between Tamaka Shwasa and age. Similarly, as far as gender is considered, Maximum number of patients $(73.08 \%)$ affected were male. No relation between the gender and Tamaka Shwasa has been established by the ancient writers. Similarly, during the modern era also, no such relation has been established. Male to female ratio was $2: 1$. Male children tend to suffer more, since they have smaller air ways for a given lung size, which is independently inherited in addition to the fact that boys have a higher incidence of respiratory infections during childhood ${ }^{8}$. Past History of Peenasa that has occurred just because of the chronic Pratishyaya further causes the Khavaigunya in Pranavaha Srotas. Role of hereditary factor in Asthma has been elicited by various studies recently. Absence of the Nrf2 gene has been found to increase the number of inflammatory cells within the airways, causing the airway lining to swell, which induces asthma in mice. Interestingly, in the present study, except for a minor percentage of $19.23 \%$, majority of the patients had a positive family history, either from the maternal or paternal side 9 . Besides them, the majority of the patients that were evaluated were secondary students. This discussion may also be taken as a fulfilment of the modern concepts of data presentation in the biostatics in medicine. When a Prakriti-wise analysis of the patients was conducted, it revealed predominance of Vata-Pitta Prakriti scoring up to $42.31 \%$. KaphaVata Prakriti was $38.46 \%$. Besides them Majority of the students were showing dominance in Rajo Guna, i.e., 
42.31\%. Proper Prakriti analysis is difficult in children because of "Sarva Dhatu Asampoornata" Still, an attempt has been made to analyze the Prakriti on the basis of current behaviour, physical features, and other physical characteristics. Moving towards Nidana, A large majority of patients in the present study $(80.77 \%)$ were consuming refrigerated food, which are Sheeta and Ruksha, regularly. $57.69 \%$ of patients were using Shleshmala Ahara. Chocolates, Takra, and Dadhi were consumed by $30.77 \%$ on a regular basis. $26.92 \%$ were taking fruits regularly. Sheeta, Vidhahi, and Vishthambhi Aahara. Abhishayandi Aahara can create the Sort Orodha and vitiate the normal path of Vata. It is having Guru Property which is heavy for digestion and hampers the function of Agni. All other Aharaja Nidana mainly act as Utpadaka as well as Preraka Hetu. Among most commonly seen Viharaja Nidanas, Sheeta Vata leads in majority (80.77\%). Exposure to dust was seen in $30.77 \%$ patients very regularly, and $19.23 \%$ were exposed to Dhuma. Divaswapna was regularly seen in $61.54 \%$ of patients. Sheeta sthana caused Shwasa Vega in $73.08 \%$ patients. These factors act as predisposing factors. Raja and Dhuma contain a number of allergens which adds to chronic airway inflammation in airways. Nidana is highly important in Swasa Roga. Primary prevention strategy in Asthma focuses on avoidance of etiological factors. Among the classical Nidana listed and also on the basis of attributes of commonly used food articles, a list of 6 Ahara Dravyas was considered in the present study for evaluation. Allergens of various types and chemical nature may act as exciting causes and produce asthma labelled as allergic asthma. The most important in this group are foods, inhalants, bacteria, emotions, and immunology. Other factors like fatigue, exhaustion, change of climate, dietetic indiscretions and exercise, weekend asthma, asthma occurring at night due to low output of adrenaline, etc., are well recognized and may play a part in the causation of disease ${ }^{8}$. Dominancy of Rasa in diet when observed, revealed surprising results that the maximum patients, i.e., $61.54 \%$, were taking Madhura Rasa Pradhana Aahara. The observation in the present study reveals that $42.31 \%$ of the patients were of Vishamashana habit, with good variation depending on the liking of food and variation in appetite. Most of the patients were having affinity to some specific food article or a specific taste, and the quantity of food intake in children generally depends on their likes and dislikes. In this study, patients were strictly advised to avoid the probable causative factors of the disease and causes for Agnimandya. This restricts almost Pathyacharana and Apathya Varjana. The role of other dietary substances including the yellow dye tartrazine, benzoate, and monosodium glutamate in exacerbating asthma is probably minimal; confirmation of their relevance requires double-blind challenge before making specific dietary restrictions ${ }^{10}$. Agni wise Present study revealed that $65.38 \%$ of patients had Mandagni and $23.08 \%$ had Vishamagni. Ama plays a key role in the Samprapti of Tamaka Shwasa. The status of Agni has to be invariably assessed in all diseases for the understanding of the etiopathology as well as its management. Jarana Sakti when taken into consideration, it was observed that $80.8 \%$ of the patients had Madhyama Jarana Shakti and remaining $11.5 \%$ patients possessed Avara Jarana Shakti. Due to the dominance of Manda and Vishama Agni, Abhyavaharana Shakti was found to be less in all the patients. When Seasonal wise study was done, it was found that Rainy season was the triggering factor in aggravation of the disease Tamaka shwasa and was observed in $53.85 \%$ of patients; Asthma is highly influenced by seasonal variation. While discussing the time of aggravation of Tamaka Shwasa, the Ayurvedic scientists have pointed out that the Shwasa Roga and particularly the Tamaka Shwasa get aggravated during the rainy season and winter season. Adverse weather conditions, such as cold temperatures, high humidity, and episodes of acute pollution brought on by weather conditions that promote the concentration of atmospheric pollutant and antigen, have been associated with Asthma exacerbations. Chronicity wise distribution of the patients was done into three groups as follows: 14 to 25 years was found in maximum patients $(65.54 \%),>25$ to 40 years was found in $26.92 \%$, and $>40$ to 50 years was found in $7.69 \%$. The diseases were of a chronic duration and their curability was never expected. So, Krichhra-Sadhyata or Yapyata 
could have been expected ${ }^{11}$. Similarly, when Intensity of attack was taken into consideration, Maximum patients had increased intensity of attack in night and midnight (53.85\%); in $50 \%$ of the patients, it was found in the morning and after physical exercise. Increasing Shwasa is observed. Frequency of attack was found daily in $26.92 \%$, weekly in $34.62 \%$, fortnightly in $30.77 \%$, and monthly in $19.23 \%$. Area wise distribution of patients revealed that Majority of patients (84.62\%) were from urban areas and $15.38 \%$ were residing in rural areas. Children in populations that migrate to urban from rural areas begin to experience a much higher prevalence of asthma when followed over a period than similar children who remain in the rural areas. The urbanized environment increases exposure to new allergens ${ }^{12}$. Srotodusti wise, it was interesting to observe the symptoms told in Prana Vaha that Sroto Dushti were present in a very high number of patients as such. Alpalpa Shwasa and Sashabda Shwasa were symptoms found in all the patients showing $76.92 \%$ incidence. Ati Badha was found in 11.54\%, Abhikshna Shwasa was seen in $46.15 \%$ of patients, Sashabda Shwasa was seen in $76.92 \%$, and Sashula Shwasa was seen in $76.92 \%$ of the patients who participated in the present clinical trial. Chief complaint wise, of the 36 patients of Tamaka Shwasa in the present clinical trial, all $(100 \%)$ had Shwasa Krichhtata or shortness of breath and Kasa as chief complaints. Peenasa was reported in 76.92\%, Ruksha Kasam in 76.92\%, Sakapha Shwasa in 19.23\%, and Parshwa Shula was seen in $34.62 \%$. Shwasakashtata is a Pratyatma Lakshana of Shwasa which is commonly associated with Kasa too, as it occurs mainly due to Srotorodha produced by Kapha in the path of Vata. So as to get the relief when patient tries to expel out the obstruction, that is why more and more cough reflex is produced; in some patients (Kapha Pradhana), it is easily expelled out, while in others (Vata Pradhana), patient has to make more efforts as in Vatic due to Sankoch in Pranavaha Sroto Nadi, usually without Kasa, or Kasa will be very troublesome and there will be no relief even after expulsion of sputum and due to excessive coughing, respiratory muscles get exhausted, so Parshva Shula is observed. Pratishyaya is a very common Nidana. In associated symptoms of Tamaka Shwasa during the attack, 50\% found relief after Kasten sleshma nirharam and Vamana. Kshavathu was seen at $46.15 \%, 34.62 \%$ was figured in the prevalence of symptoms of Shiro Greeva Parigra. Ushnopachara was reported as a relieving factor in as many as $42.31 \%$ of patients. And, 57.69\% patients reported that they get relief in sitting posture (Ashino labhate Saukhyam). Anupasaya with cold drinks which caused the vitiation of Vata and Kapha without Sanchaya due to extreme Sheeta Guna. Three patients were reported with touch of cold water as an Anupshaya. A large majority had cold drinks and refrigerated food as an aggravating factor, figuring up to $80.77 \%$. Sheeta Vata (relatively less percentage due to less habit of early rising and that is why no morning breeze exposure) was reported in $80.77 \%$, Raja in $30.77 \%$, $19.23 \%$ was found reported Dhuma (relatively less than Raja as it include only outdoor pollution containing various allergens and indoor smoke is nowadays less as all the housewives are using gas in well-ventilated kitchen), Meghambu in $53.85 \%$, Dadhi was Anupshaya in $30.77 \%$ of patients. $57.69 \%$ was found in Shleshmala Ahara, i.e., milk products and sweets. The drug BA consists of many ingredients which excellently balance each other in Rasa-Panchaka and enhance the Vata Kapha Hara, Deepana, Pachana, and Vata Anulomana properties, which are the main Doshas in pathogenesis. The main factor in this disease as in many other diseases is Ama, and the Deepana-Pachana properties of the drug will digest the Ama by kindling the Jatharagni as well as Rasagni and Bhutagni. Furthermore, the Sothaharatwa Karma of most of the contents will neutralize the Srotorodha in Pranavaha Srotas due to Sotha created by Sama Vata. The main logics behind the actions are as follows: The Dosha-Prashamana effect (Bharangi, Pippali, Sunthi, Maricha, Haridra, Kasmarda) acts on the main Doshas which contribute to the Samprapti, viz. Vata and Kapha and Guduchi and Dhanyaka Tridoshahara properties are present ${ }^{13}$. DeepanaPachana Karma (Pippali, Maricha, Guduchi, Shunthi, Dhanyaka) digest Ama. Vata Anulomana property (Pippali, Sunthi) maintains the normal flow of Vata. Shwasa, Kasa, Shothahara Prabhava (Bharangi, Vasa, 
Shunthi, Kasmarda, Pippali, Maricha, Dhanyaka) act on the symptoms. The pharmacological studies already reported on the individual drugs also favour its effect in disease bronchial asthma as given below: Antiallergic $^{14}$ - Haridra, Bharangi, Guduchi; antiinflammatory-Haridra, Guduchi, Maricha, Kasmarda, Pippali, Shunthi; antispasmodic- Vasa, Dhanyaka; Antitussive-Vasa, Shunthi; bronchodilator-Vasa, Pippali; expectorant-Vasa; immunomodulator-Pippali, Guduchi. VA has Madhura Rasa dominancy along with Tikta, Katu, and Kashaya Rasa. Sheet Veerya and Katu Vipaka contribute to the pharmacodynamics of VA. Contemplation of the ancient classics reveals no such specific property of Avaleha regarding the pharmacokinetics, except its site of action starts from the mouth. Avaleha may work as Rasayana for the Pranavaha Srotas and also shows the Kapha Vatahara effect. Antispasmodic_Vasa; expectorant-Vasa; immunomodulator- Pippali; anti-tissue Vasa; bronchodilator-Vasa, Pippali-Anti-inflammatory.

\section{CONCLUSION}

Kantkari Avaleha and Vasavaleha both showed approximately equal effect on Roga Bala. Combination of Kantakari Avaleha is very good having all the properties required to break the Samprapti of Tamaka Shwasa; however, the results are statistically not so encouraging, which may be due to the use of same formulation in both types of patients (having Vata Pradhana Samprapti and having Kapha Pradhana Samprapti).

\section{REFERENCES}

1. Goyal HR. New Delhi: Central Council for Research in Ayurveda and Siddha; 1997. A clinical study of Tamaka Shwasa (Bronchial Asthma) [Google Scholar]

2. Hemlatha N. MD Thesis Jamnagar: Gujarat Ayurved University; 2006. A clinical and experimental study on the efficacy of Shunthi Pushkaramooladi yoga in the Management of Tamaka Shwasa W.S.R. to childhood Asthma. [Google Scholar]

3. Nelson HS, Sharon Hipkins, Suzanne Rutkowski, Atkins FM. Asthma and Allergy Foundation of America. Editorial board. [Last updated on 2008 Aug]. Available from: http://www.aafa.org/display.cfm
4. Kantakari Avaleha contents in Sharanghara Madhyama Khand (8/5-9)

5. Sharma R, Sharma S. Delhi, India: Chaukhamba Sanskrit Pratisthan; 2004. Sahsrayogam Shwasa roga Chikitsa (Kshaya Prakarana) [Google Scholar]

6. Mishra Siddhi Nandan. 1st ed. Varanasi: Chaukhamba Surbharti Prakashan; 2005. Bheshajya Ratnavali, Kasa Roga Chikitsa Ref. 16/179-181. [Google Scholar]

7. Varanasi: Choukhamba Publication; 2004. Vaidya Yadavaji Trikamaji Acharya, Charaka Samhita of Agnivesha with Ayurvedadipika Commentary of Chatrapani Dutta. [Google Scholar]

8. Viswanathan J, Desai AB. 3rd ed. New Delhi, India: ICMR; 1961. Achar's Text book of Pediatrics. [Google Scholar]

9. parthasarathy A, Menon PSN, Nair MKC. 2nd ed. New Delhi, India: Parthasasthy Jaypee Brothers Medical Publishers, Ltd; 2002. IAP Textbook of Pediatrics; p. 400. [Google Scholar]

10. Bateman ED, Bousquet J, FitzGerald M, Barnes PJ. GINA Pocket guide for Asthma Management, based on the workshop report: Global Strategy for Asthma Management \& Prevention. 2008 Updated. [Google Scholar]

11. 9th ed. Varanasi: Choukhambha Orienta1 lia; 2005. Vagbhata. Ashtanga Hridaya with Commentaries, Sarvanga Sundara and Ayurveda Rasayana. [Google Scholar]

12. Parthasarathy A, Menon PS, Nair MK. 2nd ed. New Delhi: Parthasasthy Jaypee Brothers Medical Publishers Ltd; 2002. IAP Textbook of Pediatrics. [Google Scholar]

13. 10th ed. Varanasi: Chaukhamba Sanskrit Sansthan; 2002. Bhavaprakasha Nighantu.. Bhava Mishra by Brhmshankar Mishra. [Google Scholar

14. Sharma PC, Verne MB, Dennis TJ. New Delhi central council for research in Ayurveda and siddha Department of ISM\& $H$ ministry of health \& family welfare. 1-5. New Delhi: Govt. of India; 2000. Database medicinal plants. [Google Scholar]

\section{Source of Support: Nil \\ Conflict of Interest: None Declared}

How to cite this URL: Nishu Raina: Clinical Study Of Kantkari Avleha And Vasa Avleha In The Management Of Tamak Shwasa W.S.R To Bronchial Asthma. International Ayurvedic Medical Journal \{online\} 2021 \{cited January, 2021\} Available from:

http://www.iamj.in/posts/images/upload/2705 2713.pdf 